\title{
PETROGENESIS AND TECTONIC SETTING OF THE NEOPROTEROZOIC CAPITUVA K-SYENITIC MASSIF, SW MINAS GERAIS, BRAZIL
}

\author{
VALDECIR A. JANASI*
}

\begin{abstract}
RESUMO PETROGÊNESE E AMBIENTE TECTÔNICO DO MACIÇO SIENÍTICO POTÁSSICO NEOPROTEROZÓICO CAPITUVA, SW DE MINAS GERAIS. O Maciço Capitava é produto da intrusão sucessiva de quatro pulsos magmáticos principais parcialmente superpostos, compostos essencialmente por sienitos potássicos ricos em LILE. Os sienitos que constituem os três pulsos iniciais (em geral de granulação média a grossa; abreviados MCS) contrastam com os quartzo sienitos finos (FQS) que ocorrem como corpos semi-anelares no pulso final do maciço, apresentando conteúdos maiores de $\mathrm{Na}$ e $\mathrm{Al}$, e menores de $\mathrm{Si}$ e $\mathrm{Ca}$. Em função de sua granulação fina e da pequena proporção de fenocristais, as composições químicas dos FQS devem se aproximar daquelas dos magmas a partir dos quais eles cristalizaram. A presença de um componente cumulático importante em MCS pode ser também descartada, já que modelamentos químicos mostram que eles não podem derivar dos FQS por acumulação de feldspatos; mais ainda, a despeito da ampla variação textural observada, todas as amostras de MCS analisadas são quimicamente muito similares. Rochas claramente cumuláticas (lentes máficas-ultramáficas; sienitos compostos basicamente por fenocristais de feldspato alcalino) e contaminadas (biotita sienitos) parecem portanto restritas às proximidades de contatos com inclusões maiores de granitos gnáissicos encaixantes. As únicas rochas mais básicas que os MCS encontradas no maciço são mela-sienitos (IC > 35) ricos em biotita presentes no núcleo do pulso final, que não têm, contudo, composições compatíveis com a esperada para um magma parental para os sienitos mais diferenciados. Os magmas sieníticos potássicos que formaram as rochas do macico não podem ter se formado por fusão direta no manto, em vista de seus conteúdos muito baixos de $\mathrm{Ni}$ e Cr, e dos mg\# relativamente baixos. Mais provavelmente, eles derivaram de magmas básicos potássicos semelhantes a minetes (i.e., pobres em "componente basáltico"), por fracionarnento dominado por fases máficas (clinopiroxênio + olivina \pm fiogopita). As elevadas razões LILE/HFSE apresentadas pêlos sienitos estudados são similares às encontradas em magmas gerados em arcos magmáticos, mas evidências geológicas sugerem que o Maciço Capituva se formou em ambiente pós-colisional. Essa assinatura geoquímica deve portanto refletir a incorporação de material proveniente de veios ricos em LILE presentes no manto litosférico subcontinental.
\end{abstract}

Palavras-chaves: Sienito, rochas ultrapotássicas, petrologia ígnea, tectônica, litoquímica.

\begin{abstract}
The Capituva Massif, composed basically of LILE-rich potassic syenites, was made up by the successive intrusion of four main and in part superposed magmatic surges. The syenites present in the first three surges (medium- to coarse-grained syenites; MCS) differ from the fine-grained quartz syenites (FQS) that appear as ring-like bodies in the last surge, showing greater $\mathrm{Na}$ and $\mathrm{Al}$ and lower $\mathrm{Si}$ and $\mathrm{Ca}$ contents. In view of the finegrained textures and the low proportion of phenocrysts in the FQS, their compositions must not be far from those of the magmas from which they crystallized. A significant cumulative component may also be discarded for MCS, since chemical modeling show that they can not be derived from FQS by feldspar accumulation; moreover, in spite of the wide textural variation, all analyzed MCS samples are chemically very similar. Obviously cumulative (mafic-ultramafic lenses; alkali-feldspar phenocryst-rich syenites) and contaminated (biotite syenites) rocks seem thus to be restricted to contacts with major inclusions of host gneissic granites. The only rocks more mafic than MCS occurring in the massif are biotite-rich mela-syenites (color indices $>35$; at the core of the fourth surge), whose compositions are however inconsistent with that expected for a parental magma for the more differentiated syenites. The potassic syenitic magmas could not be products of direct melting of mantle sources, given their very low $\mathrm{Ni}$ and $\mathrm{Cr}$ contents, and relatively low $\mathbf{m g \#}$. More probably, they derived from basic magmas chemically akin to minettes (i.e., poor in a "basalt component"), through mafic-dominated (clinopyroxene + olivine \pm phlogopite) fractionation. The high LILE/HFSE ratios shown by the studied syenites are reminescent of those observed in magmas generated in magmatic arcs, but geologic evidence suggest that the Capituva Massif was formed in a postcollisional environment. This geochemical signature should therefore reflect the incorporation of material from LILE-rich veins in the subcontinental lithospheric mantle.
\end{abstract}

Keywords: Syenite, ultrapotassic rocks, igneous petrology, tectonics, whole-rock chemistry

INTRODUCTION Although volumetrically minor, potassic syenites occur in many granitic provinces of eastern Brazil as "late-orogenic" massifs, some reaching batholithic dimensions. Most are of Brasiliano age (Piquiri in Rio Grande do Sul, Jost el al. 1985; Bom Jardim in Pernambuco, Guimarães \& Silva Filho 1990), while the largest occurrence, the Itiúba massif in Bahia (Figueiredo 1981, Conceição et al. 1991), is late Transamazonian. Apart from differences in age and shape, they all share some remarkable features, such as a very small compositional range, a strong enrichment in LIL over HFS elements, and evidence of crystallization under very oxidizing conditions. In spite of this, different models have been proposed for the origin of these syenites. Some admit that their compositions are not far from that of the magmas from which they crystallized; these magmas could either be products of direct melting of mantle sources or be differentiated from basic (shoshonitic or ultrapotassic) mantle-derived magmas (e.g., Guimarães 1989). Others propose that the potassic syenites could be products of accumulation of alkali-feldspar from more felsic magmas (Conceição et al. 1991). Moreover, the high LILE/ HFSE ratios typical of these syenites point to a "subductionzone component" in these magmas, the origin of which is also controversial.

Two main occurrences of Neoproterozoic potassic syenite are identified to the east of the Cretaceous Pocos de Caldas massif, SW Minas Gerais: the Pedra Branca (Winters 1981) and Capituva (Janasi 1992) massifs. In this article, field, 
petrographic and geochemical features identified in the latter massif are used to address some petrologic and tectonic aspects of the potassic syenites.

GEOLOGIC SETTING The Capituva and Pedra Branca syenitic massifs occur in the central portion of the "Guaxupé Domain", an allochtonous terrane (e.g., Campos Neto et al 1984) made up of high-grade migmatitic gneisses and granulites intruded by a series of foliated granitoids (Fig. 1). The basalmost portions of this terrane are exposed towards its northern and eastern limits, where it overlies medium- to low-grade supracrustals of the Mesoproterozoic Alto Rio Grande Fold Belt (Hasui \& Oliveira 1984). Preliminary thermobarometric estimates (Vasconcellos et al. 1991) point to strong pressure gradients in the Guaxupé Domain, from values over $11( \pm 1) \mathrm{kb}$ in the lower granulites to ca. $6 \mathrm{~kb}$ in the central and southern migmatitic gneisses; peak metamorphic temperatures are high throughout (from ca. $900^{\circ} \mathrm{C}$ in the granulites to ca. $800^{\circ} \mathrm{C}$ southwards).

The migmatitic gneisses that surround the syenitic massifs (Fig. 2) can be divided into two groups, one dominated by rocks with supracrustal affinities (Caconde Complex, with garnet-biotite gneisses, quartz-rich gneisses and impure quartzites) and the other dominated by orthogneisses (Pinhal Complex). The scarce isotope (Rb-Sr and K-Ar) data available for these rocks yield exclusively Brasiliano (Neoproterozoic) ages, possibly reflecting an overprint by high-grade metamorphism.

Three main groups of Neoproterozoic foliated granitoids are recognized in the Guaxupé Domain.

Folded sill-like bodies of gneissic mangerite-charnockite-hastingsite granite with "anorogenic" geochemical fingerprints comprise the São José do Rio Pardo suite (Campos Neto et al. 1988, Janasi 1992).

A monzodiorite-quartz monzonite-syenogranite high$\mathrm{K}$ calc-alkaline suite is predominant in the southernmost portion of the Domain, where it makes up the rather large (over 1,000 sq. km) Pinhal-Ipuiúna batholith (Vasconcellos \& Janasi 1989, Haddad \& Janasi 1992).

Small, but very widespread bodies of equigranular pink granites, often intimately associated with migmatites (the "Pinhal-type granites", Wernick \& Penalva 1980, Janasi \& Ulbrich 1991), are interpreted as products of partial melting of the older gneisses during the high-grade Brasiliano metamorphism.

The intrusion of the syenitic massifs seems to post-date the main displacement of the allochthonous terrane, since they lack the strong tectonic foliation found in the country rocks, and estimates of depth of emplacement yield values significantly lower than the $\mathrm{ca} .7 \mathrm{~kb}$ reported in the foliated mangerites (Janasi 1992).

GEOLOGY The geology and petrography of the Capituva Massif are described in detail in Janasi (1992 and in preparation), and only some relevant aspects will be presented here.

The massif has an ellipsoidal shape (elongated N40W; $16,5 \times 11 \mathrm{~km}$ ) which resulted from the sequential intrusion of four partially superposed magmatic surges (Fig. 2). The bulk of the first three surges is made up of modally monotonous syenites (color indices, 20-25) which show, however, important textural variations that point to progressively slower crystallization in the younger facies. As such, the group hereafter referred to as "medium to coarse-grained syenites" (MCS) includes a variety of facies, that change from marginal porphyritic to central medium- to coarsegrained laminated syenites mostly by coarsening of the groudmass and reduction of the abundance of K-feldspar megacrysts. Although the overall tendency is well-defined

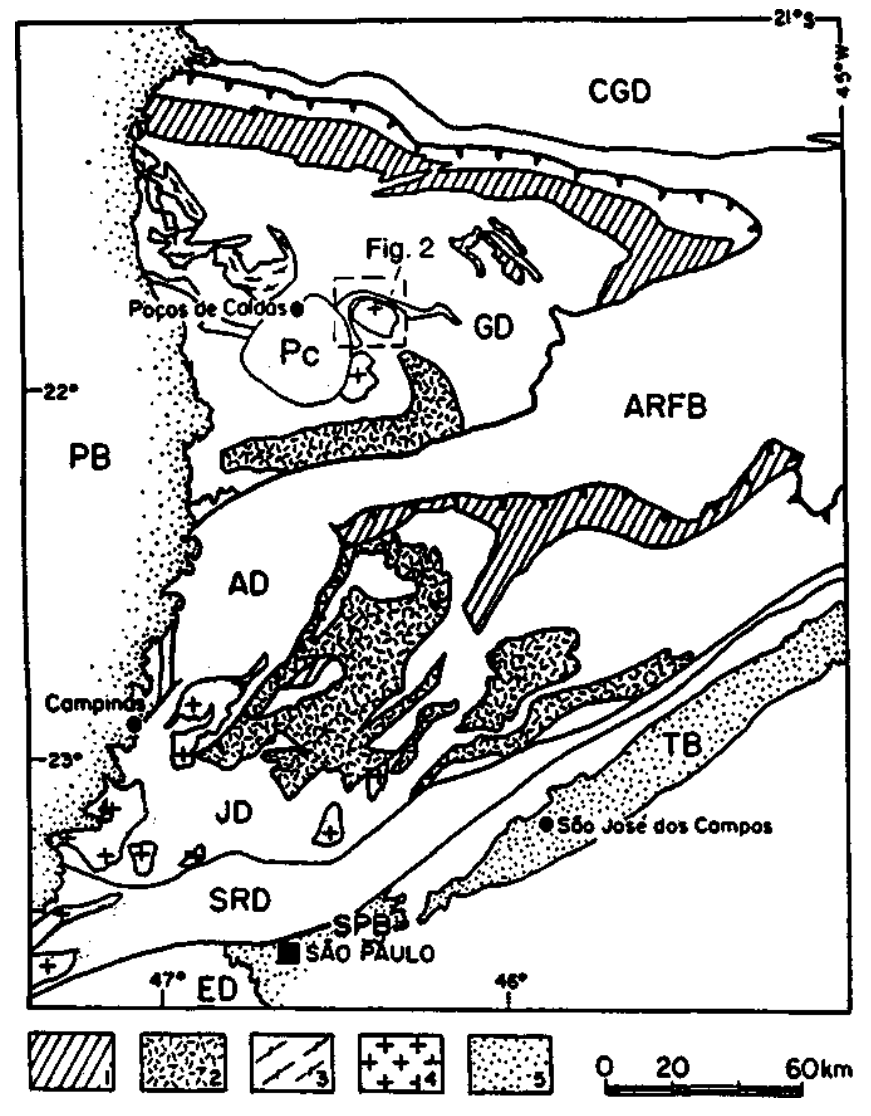

Figure 1-Geologic context of the Capituva Syenitic Massif (modified from Vasconcellos 1988). Proterozoic Geologic Domains: $\boldsymbol{C G D}=$ Campos Gerais; $\boldsymbol{G D}, \boldsymbol{J D}=$ Guaxupé and Jundiai (together comprising the Socorro-Guaxupé Thrust Nappe); $\boldsymbol{A D}, \boldsymbol{A R F B}=$ Amparo Domain, part of the Alto Rio Grande Fold Belt; $\mathbf{S R D}=$ São Roque; $\boldsymbol{E D}=E m b u$. Symbols: 1. granulites; 2. "syn-orogenic" calc-alkaline granitoid batholiths; 3. São José do Rio Pardo mangeritecharnockite-granite suite; 4. "late-orogenic" granitoids (Itu belt); 5. Phanerozoic Sedimentary Basins $(\boldsymbol{P B}=$ Paraná $; \boldsymbol{S P B}=$ São Paulo; $\boldsymbol{T B}=$ Taubate): $\boldsymbol{P C}=$ Poços de Caldas alkaline massif

Figura 1 - Contexto geológico do Maciço Sienítico Capituva (modificado de Vasconcellos 1988). Domínios Geológicos Protemzóicos: CGD = Campos Gerais; GD, JD = Guaxupé and Jundiaí (juntos constituindo a Nappe de Empurrão Socorro-Guaxupé); AD, ARFB = Domínio Amparo, parte da Faixa Dobrada Alto Rio Grande; SRD= São Roque; $\mathbf{E D}=$ Embu. Símbolos: 1. granulitos; 2. batólitos granitóides cálcio-alcalinos "sin-orogênicos";

3. Suíte mangerítica-charnoquítuca-granítica São José do Rio Pardo;

4. granitóides "tardi-orogênicos" (Cinturão Itu); 5. Bacias sedimentares fanerózoicas ( $\mathrm{PB}=$ Paraná; $\mathrm{SPB}=$ São Paulo; $\mathrm{TB}=$ Taubaté); $\mathrm{Pc}=$ Maciço Alcalino Poços de Caldas

and often transitional, the contacts among the facies are locally sharp, as shown by truncations on a map scale (defining the different surges) and by the intrusive character of the coarser facies in some outcrops. Inclusions and possible roof pendants of gneissic granite are very common within the massif (Fig. 2); centimetric mafic-ultramafic lenses and a facies of very coarse-grained syenites, both interpreted as cumulative rocks, are found next to them (Janasi 1992).

The fourth magmatic surge is the most complex, and exhibits a core of porphyritic mela-syenite (MS; color indices over 35 ) bordered by laminated coarse-grained syenites 

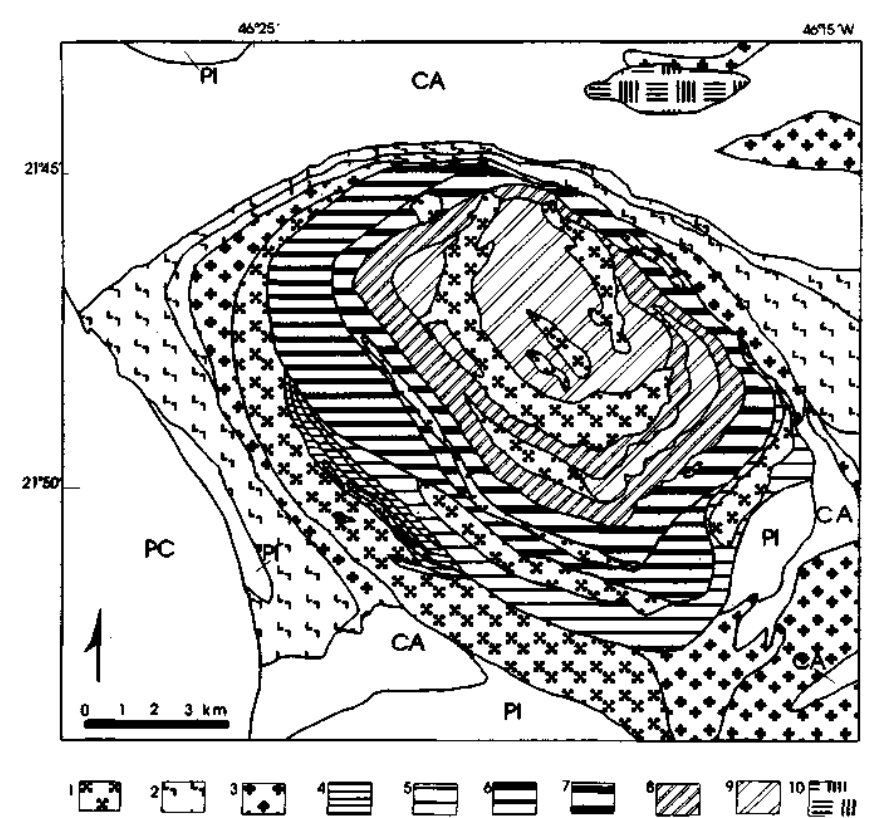

Figure 2 - Simplified geologic map of the Capituva Massif and country rocks. $\boldsymbol{C A}$ - supracrustal rocks (Caconde Complex); PI = granitic orthogneisses (Pinhal Complex); $\boldsymbol{P C}=$ Pogos de Caldas Alkaline Massif (cretacic). Symbols: 1. porphyritic calc-alkaline gneissic granitoids; 2. mangerite-charnockite-granite suite; 3. pink ecjuigranular migmatitic granites; 4 to 10. Capituva Syenitic Massif. 4 to 6, MCS facies; 4. coarse-grained laminated syenites and porphyritic syenites with fine-grained matrix (surge 1); $\mathbf{5}$. porphyritic syenites with fine- to medium-grained matrix (surge 2)); 6. medium-grained laminated syenites (surge 3); 7 to 9, surge 4; $N=7$. coarse-grained laminated syenites; 8. fine-grained and fine- to medium-grained quartz syenites (FOS and FMOS, respectively); 9. mela-syenites (MS); 10. satellyte body, mainly with leuco-syenites

Figura 2 - Mapa geologico simplificado do maciço Capituva e rochas encaixantes. $\mathbf{C A}=$ predomínio de rochas supracrustais (Complexo Caconde); PI $=$ ortognaisses granitóides (Complexo Pinhal); $\mathbf{P C}=$ Maciço Alcalino Poços de Caldas. Símbolos: 1. granitóides gnáissicos cálcio-alcalinos; 2. suíte mangerito-charnoquito-granítica; 3 . granites equigranulares róseos migmatíticos; 4 a 10. Maciço Sienítico Capituva. 4 a 6, facies MCS; 4. sienitos laminados grossos e sienitos porfiríticos com matrix fina (pulso 1); $\mathbf{5}$. sienitos porfiríticos com matriz fina a média (pulso 2); 6 . sienitos laminados médios (pulso 3); 7 a 9, pulso 4; 7. sienitos laminados grossos; 8. quartzo sienitos finos e finos a médios (FQS e FMQS); 9. mela-sienitos (MS); 10 corpo satélíte com leuco-sienitos predominantes

which host ring-shaped bodies of fine- and fine- to mediumgrained quartz syenite (FQS; FMQS; Fig. 2). Whilst the whole of the massif is deeply weathered and difficult to sample, the area occupied by the mela-syenites is the most poorly exposed. The contacts with the laminated coarsegrained syenites are apparently transitional, though it is possible that the mela-syenites are intrusive and their compositional diversity results from variations in the degree of contamination by these rocks (Janasi 1992). In the ring-like areas mapped as FQS and FMQS, these finer-grained rocks occur as a series of (normally decimetric to centimetric) lenses complexly intermingled with laminated coarsegrained syenites (Janasi 1992).

The country rocks are arranged in an almost concentric pattern around the massif, although in detail their contacts are obviously truncated by the syenites. The geometric disposition of the tectonic foliation of the wall rocks and that of the magmatic foliation of the syenites (present in all facies, but more obvious in the laminated facies) suggests the shape of a funnel inclined to the SW for the massif. The overall structure seems to be the result of a forceful intrusion during a late NE-SW directed regional deformational phase (Janasi 1992).

PETROGRAPHY Except for the mela-syenites, all syenites from the Capituva Massif seem to have been devoid of magmatic plagioclase, and could thus be described as "hypersolvus". Almost all rocks, however, experienced strong post-magmatic recrystallization, which generated secondary oligoclase $(\mathrm{An}<20)$ by exsolution from the original alkali-feldspar. The mela-syenites show magmatic groundmass plagioclase (ca. An22) in equilibrium with $\mathrm{K}$-feldspar, owing to their more calcic chemistry (Janasi 1992). Scattered relicts of partly resorbed zoned plagioclase (with cores as calcic as An40) are found within K-feldspars of some of the most fine-grained syenites, where they failed to react with the magma owing to rapid crystallization.

The original compositions of the alkali-feldspars are difficult to estimate, since they are strongly perthitic; nevertheless, values around Or60 were obtained by reintegrations of less recrystallized tabular crystals in laminated facies (made under the microprobe, by continuously shifting a large electron beam throughout the entire crystal). Most FQS exhibit nicely zoned alkali-feldspar phenocrysts with subhedral cores approaching anorthoclase-sodic orthoclase compositions $(\mathrm{Or}<50)$ mantled by rather irregular potassic rims whose compositions $(\mathrm{Or}>70)$ match those of the matrix alkali-feldspar.

Edenitic hornblende, the main mafic mineral in MCS, is mostly of late- to post-magmatic origin, and may exhibit relict cores of diopside; this clinopyroxene, in turn, predominates in the least recrystallized FQS and MS. Orthopyroxene was identified in a single sample of FQS, as partly resorbed crystals totally surrounded by clinopyroxene. Biotite is subordinate and partly secondary (mostly after hornblende) in MCS, but is typically abundant in MS, and may form scattered megacrysts and partly surround clinopyroxenes in some FQS. Primary quartz is absent in MS, and may reach $7-8 \%$ in volume in FQS, where it occurs in the groundmass and as rounded inclusions in the rims of alkali-feldspar phenocrysts.

Ilmenite with abundant hematite lamellae (up to 30-40\% Hem component) is the sole primary opaque oxide in all facies. Apatite is abundant (up to $1.5 \%$ modal), and occurs in FQS both as phenocrysts and as minute matrix crystals. Other minor accessories are allanite and zircon. Titanite is typically absent in less recrystallized rocks; whenever present, it is restricted to rims around ilmenite and to inclusions in biotite. Even more uncommon are lowertemperature secondary minerals, such as magnetite, sulfides (pyrite and minor chalcopyrite) and actinolite.

WHOLE-ROCK CHEMISTRY Analytical techniques Major, minor and trace element analyses were done by ICP at the Analytical Facility of the Imperial College in London (analyst, Peter Watkins), except REE (by ICP), $\mathrm{Nb}$ and $\mathrm{Y}$ (by XRF), both done at GEOLAB, Belo Horizonte, and $\mathrm{Rb}$ and $\mathrm{Sr}$ (by XRF), at the Centre de Pesquisas Geocronológicas, Institute de Geociências, Universidade de São Paulo. The estimated accuracy for major elements is $1 \%$ (relative); the trace element contents analyzed at the Imperial College are within $\pm 15 \mathrm{ppm}$.

Chemical variations Only thirteen rock samples obtained in the Capituva Massif were fresh enough for chemical analyses, even though intensive sampling programs 
were developed with this purpose. The sampling is somehow biased towards the fine-grained quartz syenites; the few samples obtained from the coarser MCS fades come from exposures in drainage beds. Only one sample of melasyenite was obtained, and thus the chemical variation within this rock group cannot be evaluated.

The analyses (Tab. 1, Fig. 3) illustrate the small chemical variation identified in the Capituva Massif. Plots of major and trace elements do not define usual trends, but emphasize the existence of different chemical groups. FQS are richer in $\mathrm{SiO}_{2}$ and $\mathrm{CaO}$ and poorer in $\mathrm{Al}_{2} \mathrm{O}_{3}$ and $\mathrm{Na}_{2} \mathrm{O}$ than $\mathrm{MCS}$, while the $\mathrm{MgO}$ contents remain at the same level (ca. $3 \%$ ) for both groups. As a result, FQS are comparatively richer in normative diopside and poorer in anorthite and albite. FQS also show slightly higher $\mathrm{Ba} / \mathrm{Sr}$ ratios (Fig. 4). A more differentiated (silica-rich) sample of MCS (CA474b) shares the most important features of its group, except those related to the abundance of mafic minerals (e.g., the $\mathrm{Mg}$ and $\mathrm{Fe}$ contents). The chemical gap between these two groups is partly filled by FMQS, that occur in the northern part of the same ring-like bodies where FQS appear. The only analyzed sample of MS is more basic, and it is not clearly related to any of the other syenite groups.

The five samples of different facies analyzed for REE show strikingly similar chondrite-normalized patterns (Tab. 2, Fig. 5), all strongly fractionated $(\mathrm{La} / \mathrm{Yb}(\mathrm{n})=40-50)$ and lacking significant Eu anomalies $\left(\mathrm{Eu} / \mathrm{Eu}^{*}=0.87-0.93\right)$. The analyzed FQS is slightly less fractionated $(\mathrm{La} / \mathrm{Yb}(\mathrm{n})=$ 33), while the mela-syenite has lower LREE/MREE and HREE/MREE (Fig. 5)
Possible causes of variation The analyzed samples are plotted in the normative feldspar diagram in figure 6 . Also plotted as a reference is the solvus for ternary feldspars (LKS line) and the cotectic-peritectic plagioclase-alkali feldspar line (PAL) for the quartz-free system at $\mathrm{a}\left(\mathrm{H}_{2} \mathrm{O}\right)=$ 0.1 , according to the calculations of Nekvasil (1990). In spite of the small variation, an apparent trend of diminishing "plagioclase" content can be devised from MCS to FQS, whose compositions lie closer to the PAL line. As described previously, plagioclase is not a primary mineral in the MCS, which is in agreement with the location of their bulk compositions, within the ternary feldspar field (below the LKS line). This obviously rules out models relating these syenites to the accumulation of plagioclase from magmas chemically similar to FQS. On the other hand, plagioclase did crystallize in the early stages of solidification of the syenitic magmas (as substantiated by the occurrence of resorbed relicts within alkali feldspars of some FQS and otherwise predicted by the location of the compositions within the CKS area of the diagram; see Nekvasil 1990), and thus the observed chemical trend could be explained by the extraction of some plagioclase from magmas chemically similar to the medium- to coarse-grained syenites. Another interesting aspect of the diagram is that the sample of mela-syenite (located outside the ternary feldspar field, which agrees with the occurrence of two feldspars in its groundmass) is not located in an extension of the above trend. In fact, quantitative major element modeling shows that the MS composition does not correspond to an adequate primary melt to derive the more felsic syenites (Janasi 1992).

Table 1-Chemical analyses of syenites from the Capituva Massif. $\left.\boldsymbol{m g \# - 1 0 0 *} \mathrm{Mg} / \mathrm{Mg}^{+} \mathrm{Fe}^{2+}\right)$, cationic proportions; $\mathrm{A} / \mathrm{CNK}$ $=\mathrm{Al}_{2} \mathrm{O}_{3} / \mathrm{CaO}+\mathrm{Na}_{2} \mathrm{O}+\mathrm{K}_{2} \mathrm{O}$, molecular proportions; $\boldsymbol{n}$.d. - not determined

Tabela 1 - Resultados de análises químicas de sienitos do Maciço Capituva. mg\#=100* $\mathrm{Mg} /\left(\mathrm{Mg}+\mathrm{Fe}^{2+}\right) ; \mathbf{A} / \mathbf{C N K}=\mathrm{Al}_{2} \mathrm{O}_{3} / \mathrm{CaO}+\mathrm{Na}_{2} \mathrm{O}+\mathrm{K}_{2} \mathrm{O}$, proporções moleculares; $\mathbf{n . d}$ = não- determinado

\begin{tabular}{|c|c|c|c|c|c|c|c|c|c|c|c|c|c|}
\hline $\begin{array}{l}\text { Sample } \\
\text { Facies }\end{array}$ & $\begin{array}{l}\text { CA974a } \\
\text { MS }\end{array}$ & $\begin{array}{l}\text { CA422 } \\
\text { MCS } \\
\end{array}$ & $\begin{array}{l}\text { CA474b } \\
\text { MCS }\end{array}$ & $\begin{array}{l}\text { CA396 } \\
\text { MCS }\end{array}$ & $\begin{array}{l}\text { CA369b } \\
\text { MCS }\end{array}$ & $\begin{array}{l}\text { CA1103 } \\
\text { MCS }\end{array}$ & $\begin{array}{l}\text { CA241 } \\
\text { FMQS }\end{array}$ & $\begin{array}{l}\text { CA881 } \\
\text { FMQS }\end{array}$ & $\begin{array}{l}\text { CA992d } \\
\text { FMQS }\end{array}$ & $\begin{array}{l}\text { CA869b } \\
\text { FQS }\end{array}$ & $\begin{array}{l}\text { CA952 } \\
\text { FQS }\end{array}$ & $\begin{array}{l}\text { CA957 } \\
\text { FQS } \\
\end{array}$ & $\begin{array}{l}\text { CA28b } \\
\text { FQS } \\
\end{array}$ \\
\hline $\mathrm{SiO}_{2}$ & 52.91 & 56.40 & 60.83 & 56.62 & $\begin{array}{r}57.21 \\
\end{array}$ & 58.07 & 58.37 & 58.95 & 59.01 & 59.46 & 59.75 & 60.17 & 60.54 \\
\hline $\mathrm{TiO}_{2}$ & 2.01 & 1.62 & 1.23 & 1.62 & 1.57 & 1.56 & 1.64 & 1.57 & 1.51 & 1.46 & 1.41 & 1.44 & 1.42 \\
\hline $\mathrm{Al}_{2} \mathrm{O}_{3}$ & 14.66 & 15.09 & 15.94 & 15.40 & 15.56 & 14.69 & 14.63 & 14.25 & 14.83 & 13.87 & 14.23 & 13.85 & 13.81 \\
\hline $\mathrm{Fe}_{2} \mathrm{O}_{3}$ & 8.23 & 6.96 & 5.27 & 6.67 & 6.66 & 6.21 & 6.06 & 6.28 & 6.68 & 5.69 & 5.94 & 5.74 & 5.69 \\
\hline MnO & 0.10 & 0.09 & 0.07 & 0.10 & 0.08 & 0.08 & 0.08 & 0.10 & 0.10 & 0.09 & 0.09 & 0.08 & 0.09 \\
\hline $\mathrm{MgO}$ & 4.40 & 3.30 & 2.09 & 2.88 & 2.99 & 2.93 & 3.01 & 3.02 & 2.90 & 3.05 & 2.90 & 3.13 & 3.02 \\
\hline $\mathrm{CaO}$ & 5.86 & 4.22 & 3.07 & 4.17 & 3.98 & 4.01 & 4.76 & 4.89 & 4.47 & 4.34 & 4.31 & 4.67 & 4.39 \\
\hline $\mathrm{Na}_{2} \mathrm{O}$ & 3.19 & 3.82 & 3.96 & 3.69 & 3.68 & 3.60 & 3.45 & 3.37 & 3.65 & 3.14 & 3.27 & 3.26 & 3.04 \\
\hline $\mathrm{K}_{2} \mathrm{O}$ & 5.98 & 6.05 & 6.14 & 5.92 & 6.10 & 5.75 & 6.26 & 6.32 & 5.79 & 6.48 & 6.37 & 5.76 & 6.53 \\
\hline $\mathrm{P}_{2} \mathrm{O}_{3}$ & 1.29 & 0.97 & 0.64 & 1.04 & 1.09 & 1.02 & 1.07 & 1.05 & 0.92 & 0.95 & 0.94 & 0.88 & 0.94 \\
\hline P.F. & 0.81 & 0.46 & 0.46 & 0.49 & 0.43 & 0.57 & 0.42 & 0.25 & 0.26 & 0.26 & 0.23 & 0.24 & 0.37 \\
\hline Total & 99.44 & 98.98 & 99.70 & 98.60 & 99.35 & 98.49 & 99.75 & 100.05 & 100.12 & 98.79 & 99.44 & 99.22 & 99.84 \\
\hline $\mathrm{Ba}$ & 5500 & 3450 & 3000 & 3790 & 3960 & 3800 & 4260 & 4040 & 3740 & 3790 & 3600 & 3230 & 3660 \\
\hline Sr & 2645 & 2067 & 1842 & 2355 & 2522 & 2360 & 2381 & 2490 & 2040 & 2093 & 1809 & 1898 & 1986 \\
\hline $\mathbf{R b}$ & 140 & 136 & 157 & 140 & 116 & 126 & 129 & 131 & 132 & 170 & 186 & 145 & 175 \\
\hline $\mathrm{Zr}$ & 380 & 350 & 380 & 420 & 390 & 335 & 315 & 340 & 360 & 420 & 345 & 280 & 420 \\
\hline $\mathrm{La}$ & 100 & 105 & 90 & 110 & 115 & 100 & 10 & 120 & 110 & 95 & 95 & 70 & 110 \\
\hline Nb & 14 & n.d. & 15 & n.d. & 14 & n.d. & n.d. & 15 & n.d. & n.d. & n.d. & n.d. & 15 \\
\hline $\mathbf{Y}$ & 36 & n.d. & 32 & n.d. & 31 & n.d. & n.d. & 46 & n.d. & n.d. & n.d. & n.d. & 39 \\
\hline $\mathbf{Z n}$ & 110 & 85 & 80 & 80 & 90 & 75 & 85 & 80 & 100 & 75 & 80 & 65 & 100 \\
\hline Co & 30 & 20 & 15 & 20 & 20 & 15 & 20 & 20 & 20 & $<15$ & 15 & $<15$ & 20 \\
\hline $\mathrm{Cr}$ & 90 & 50 & 45 & 60 & 70 & 70 & 60 & 65 & 55 & 80 & 65 & 100 & 85 \\
\hline $\mathrm{Cu}$ & 45 & 25 & 20 & 20 & 30 & 20 & 30 & 20 & 30 & 15 & 15 & 20 & 30 \\
\hline $\mathrm{Ni}$ & 65 & 30 & $<15$ & 25 & 40 & 25 & 40 & 40 & 30 & 30 & 40 & 40 & 55 \\
\hline v & 110 & 85 & 95 & 115 & 115 & 105 & 100 & 100 & 105 & 80 & 90 & 90 & 95 \\
\hline mg\# & 51.4 & 48.4 & 44.0 & 46.1 & 47.1 & 48.3 & 49.6 & 48.8 & 46.3 & 51.5 & 49.2 & 51.9 & 51.3 \\
\hline & 0.66 & 0.74 & 0.85 & 0.77 & 0.78 & 0.76 & 0.69 & 0.67 & 0.73 & 0.69 & 0.71 & 0.69 & 0.69 \\
\hline
\end{tabular}



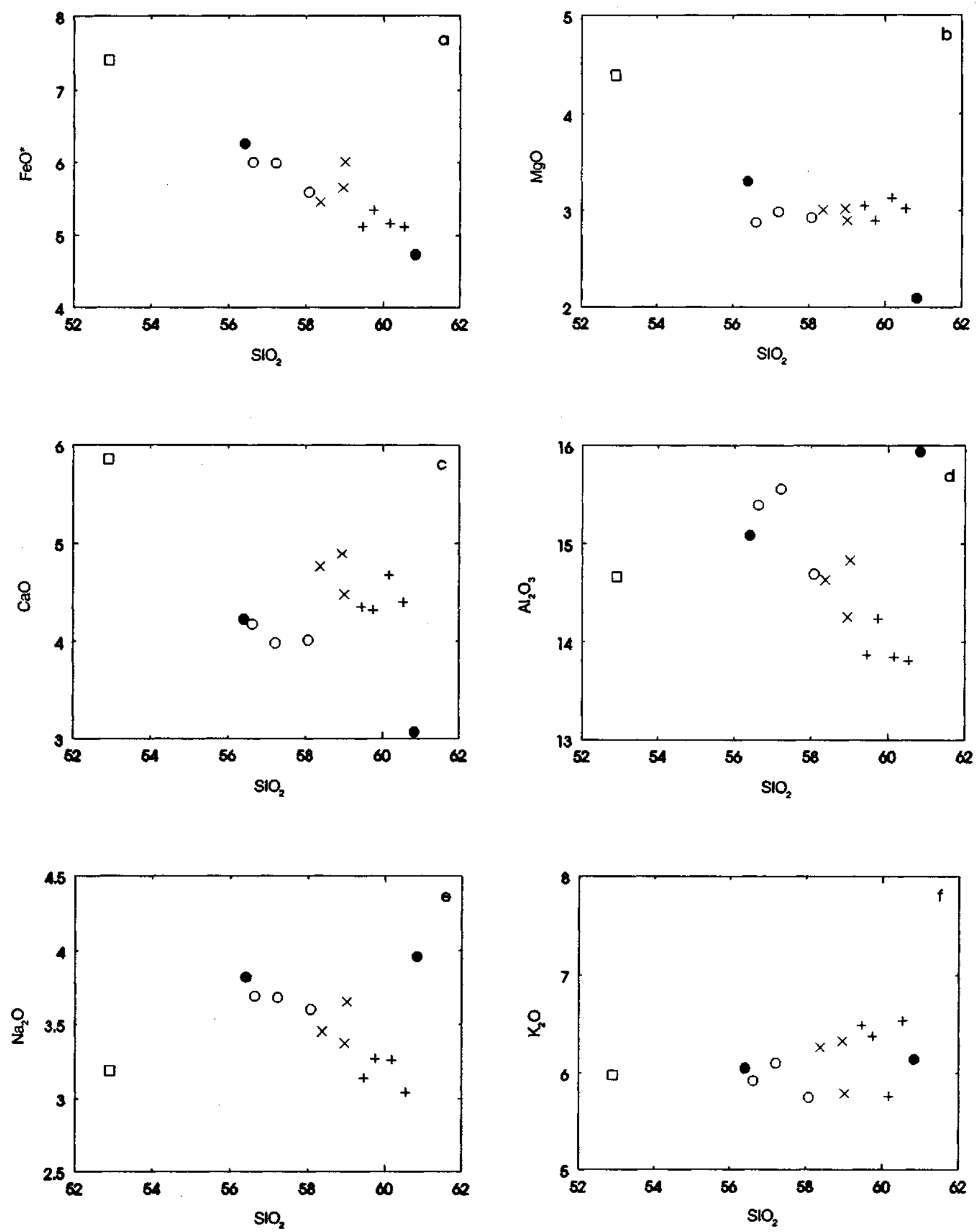

Figure 3 - Marker diagrams for Capituva Syenites. Symbols: open square = MS; circles = MCS (open, laminated syenites; closed, porphyritic syenites); $(x)=F M Q S$; crosses = FQS

Figura 3 - Diagramas de Marker para sienitos do Maciço Capituva. Símbolos: quadrado vazio = MS; círculos = MCS (vazios, sienitos laminados; cheios, sienitos porfiríticos); $(\mathrm{x})=\mathrm{FMQS}$; cruzes $=\mathrm{FQS}$ 

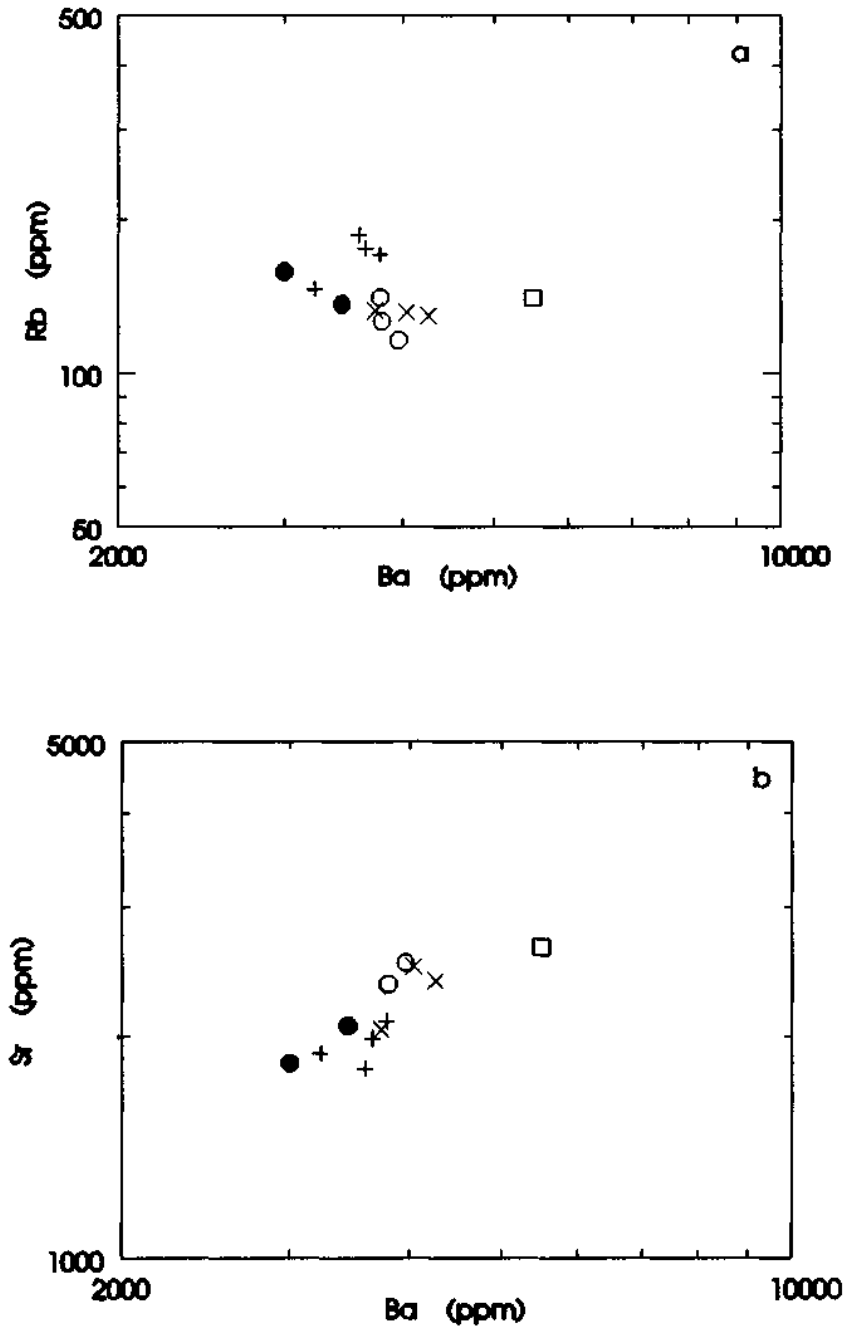

Figure 4 - Rb vs. Ba and Rb vs. Sr variation diagrams for Capituva Syenites. Symbols as in figure 3

Figura 4 - Diagramas de variação $\mathrm{Rb} v s$. Ba e Rb vs. Sr para sienitos do Maciço Capituva. Símbolos como na figura 3

\section{Table $2-R E E$ contents of selected samples of Capituva} Syenites

Tabela 2- Conteudo de elementos terras-raras em amostras selecionadas de sienitos do Maciço Capituva

\begin{tabular}{l|rrrrr}
\hline Sample & CA974a & CA369b & CA474b & CA881 & CA28b \\
Unit & MS & MCS & MCS & FMQS & FQS \\
\hline $\mathrm{La}$ & 79.60 & 102.80 & 83.31 & 104.10 & 96.98 \\
$\mathrm{Ce}$ & 189.10 & 232.30 & 184.50 & 250.80 & 215.10 \\
$\mathrm{Nd}$ & 106.60 & 114.80 & 80.66 & 122.60 & 102.90 \\
$\mathrm{Sm}$ & 16.87 & 18.12 & 12.60 & 19.72 & 16.27 \\
$\mathrm{Eu}$ & 3.79 & 4.06 & 2.72 & 4.39 & 3.48 \\
$\mathrm{Gd}$ & 9.83 & 9.92 & 7.10 & 11.12 & 9.18 \\
$\mathrm{Dy}$ & 4.90 & 5.58 & 4.08 & 6.09 & 5.41 \\
$\mathrm{Ho}$ & 0.92 & 1.04 & 0.75 & 1.14 & 1.04 \\
$\mathrm{Er}$ & 2.14 & 2.41 & 1.70 & 2.71 & 2.60 \\
$\mathrm{Yb}$ & 1.08 & 1.61 & 1.02 & 1.84 & 1.98 \\
Lu & 0.14 & 0.27 & 0.14 & 0.24 & 0.27 \\
\hline La/Yb(N) & 49.74 & 43.05 & 55.01 & 38.23 & 32.96 \\
Eu/Eu* & 0.90 & 0.93 & 0.88 & 0.91 & 0.87 \\
\hline
\end{tabular}
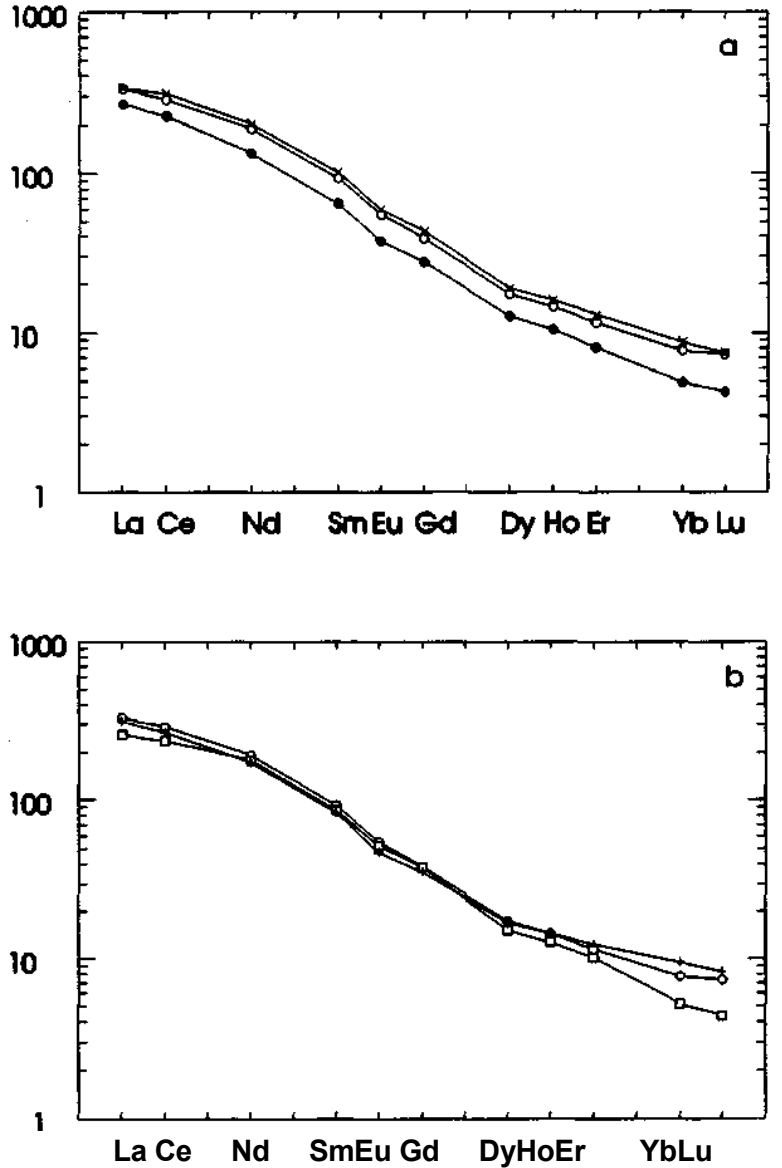

Figure 5 - REE patterns for rocks from the Capituva Massif, normalized by the chondritic values of Boynton (1984). Symbols: closed circle, porphyritic MCS CA474b; open circle, laminated MCS CA369b; (x), FMQS CA881; open square, MS CA974a; cross, FQS CA28b Figura 5 - Padrões de REE para rochas do maciç Capituva, normalizados pelos valores condríticos de Boynton (1984). Símbolos: círculo cheio, MCS porfirítico CA474b; círculo vazio, MCS laminado CA369b; (x), FMQS CA881; quadrado vazio, MS CA974a; cruz, FQS CA28b

The more differentiated character of the FQS is also illustrated by their higher quartz-normative contents and by the slightly lower $\mathrm{TiO}_{2}$ and $\mathrm{P}_{2} \mathrm{O}_{5}$ contents as compared to the MCS (Tab. 1). The maintenance of relatively high $\mathrm{MgO}$ contents in these FQS reflects the influence of high $\mathrm{fO}_{2}$ in the magmas, conditioning the early crystallization (and potential fractionation) of $\mathrm{Fe}^{3+}$-rich ilmenite. The $\mathrm{CaO}$ contents in FQS are higher than those of the MCS, precluding any significant fractionation of Ca-pyroxene from magmas chemically identical to these syenites. Major element modeling through the XLFRAC program (Stormer \& Nicholls 1978) suggests that most probably these two syenite groups derived from slightly different parental magmas (Janasi 1992).

Geochemical affinities In spite of the small variations described above, the studied syenites behave as an extremely coherent chemical group, and share some very distinctive features that are even more pronounced in the trace elements. Of particular significance are their remarkably high potassium contents, placing them above the lower limit for shoshonitic rocks in $\mathrm{K}_{2} \mathrm{O} \times \mathrm{SiO}_{2}$ diagrams (Fig. 7). As such, their high $\mathrm{K}_{2} \mathrm{O} / \mathrm{Na}_{2} \mathrm{O}$ (well above unity) would classify the predominant syenites as equivalents of latites in 


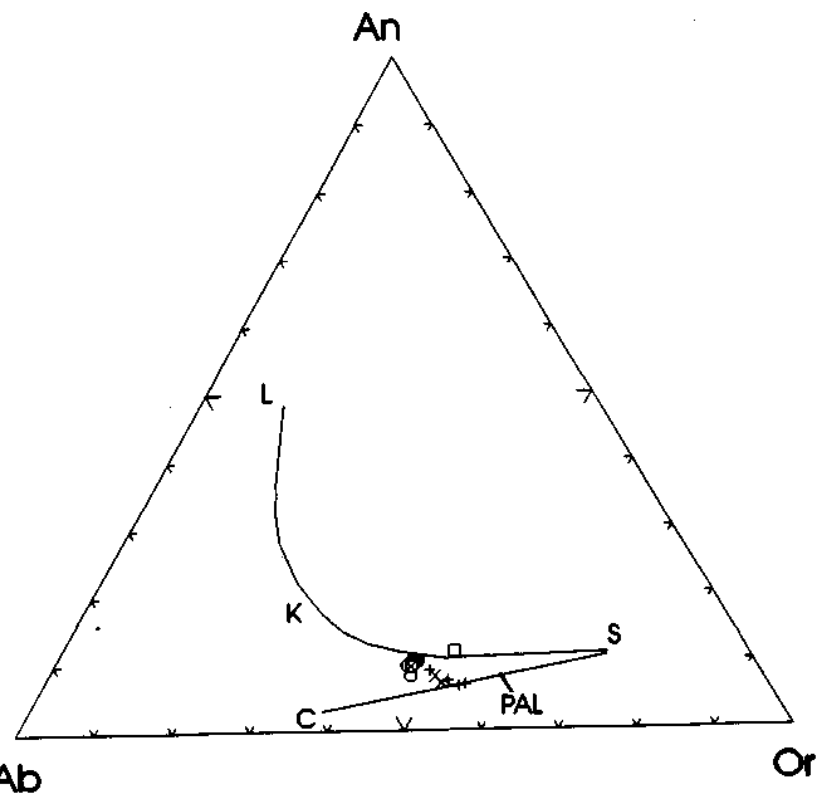

Figure 6 - Normative feldspar compositions of the Capituva Syenites (CIPW norm; weight percent) plotted in the Ab-AnOr diagram. Also indicated are the solvus for ternary feldspars (LKS; K = consolute point) and the cotecticperitectic plagioclase-alkali feldspar line (PAL) for the quartz-free system at $2 \mathrm{~kb}$ and $a\left(\mathrm{H}_{2} \mathrm{O}\right)=0.1$ (from Nekvasil 1990). Symbols as in figure 3

Figura 6 - Composições dos sienitos do Maciço Capituva em diagrama de feldspatos normativos no diagrama Ab-An-Or (normas CIPW; porcentagens em peso). São também indicados o solvus para feldspatos ternarios (LKS; K= ponto consoluto) e a linha cotética-peritética plagioclásio-feldspato alcalino (PAL) para o sistema sem quartzo a $2 \mathrm{~kb}$ e a $\left(\mathrm{H}_{2} \mathrm{O}\right)=0,1$ (segundo Nekvasil 1990). Símbolos como na figura 3

al. (1986); the mela-syenite would in fact be equivalent to a shoshonite. Perhaps more significantly, these rocks, with $\mathrm{K}_{2} \mathrm{O}$ contents around $6 \%$ even at $\mathrm{MgO}$ above $3 \%$, could be classified as ultrapotassics in the nomenclature of Foley et al (1987, also Foley 1992).

The high $\mathrm{K}$ abundance is, as usual, accompanied by high LILE and LREE. The HFSE of equivalent incompatibility, however, do not accompany this level of enrichment, which results in pronounced valleys for elements such as $\mathrm{Nb}$ and Ti in chondrite-normalized diagrams (Fig. 8). These patterns characterize the potassic rocks included by Rogers (1982) in the "high K/Ti group", which for many authors would reflect the influence of a "subduction-zone component"; accordingly, these high LILE/HFSE ratios (e.g., Rb/ $(\mathrm{Nb}+\mathrm{Y}) ; \mathrm{La} / \mathrm{Nb}$ ) would classify them as "volcanic arcrelated" in trace-element discrimination diagrams (Pearce et al. 1984, Thompson \& Fowler 1986; see below).

IGNEOUS PETROLOGY: THE ORIGIN OF THE CAPITUVA K-SYENITES As outlined above, the rocks from the Capituva massif span a restricted compositional range, a situation not much different from that observed in other K-syenitic occurrences (e.g., Thompson \& Fowler 1986, Conceição et al. 1991, Jost et al. 1985). The only common mafic rocks encountered in the massif are the mafic-ultramafic lenses described previously, which are of obvious cumulative nature. Mafic enclaves with textures indicative of a non-cumulative origin appear to be absent, and in any case their observation would be very difficult given the strong weathering of most outcrops. The same is true for more felsic ("granitic") rocks: these were observed only as small irregular patches of biotite ( \pm hornblende)

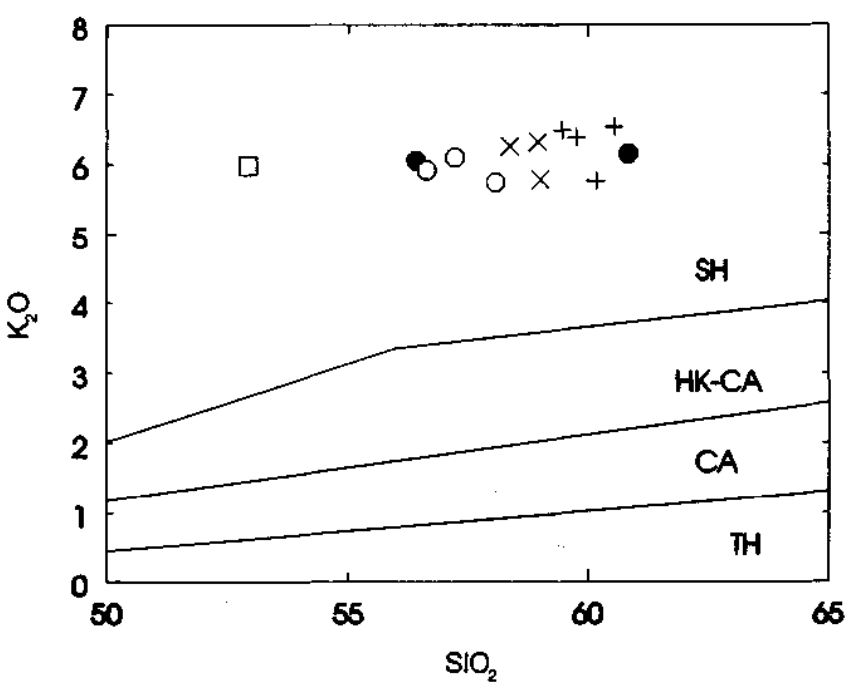

Figure $7-\mathrm{K}_{2} \mathrm{O}$ vs. $\mathrm{SiO}_{2}$ diagram for the Capituva syenites. Compositional fields, according to Peccerillo \& Taylor (1976); $\boldsymbol{T H}=$ tholeiitic series; $\boldsymbol{C A}=$ calc-alkaline series; $\boldsymbol{H K}-\boldsymbol{C A}=$ high-K calc-alkaline series; $\boldsymbol{S H}=$ shoshonitic series. Symbols as in figure 3

Figura 7 - Diagrama $\mathrm{K}_{2} \mathrm{O}$ vs. $\mathrm{SiO}_{2}$ para sienitos do Maci9o Capituva. Campos composicionais, segundo Peccerillo \& Taylor (1976); $\mathbf{T H}=$ série toleítica; $\mathbf{C A}$ = série cálcio-alcalina; HK-CA = série cálcio-alcalina de alto potássio; $\mathbf{S H}=$ série shoshonítica

granite or pegmatite near the contacts of the massif, and could well correspond to products of contamination and/or anatexis of the country rocks (Janasi 1992). Attempts at relating these K-syenites to magmatic series would be therefore somehow speculative, though certainly of foremost importance for their petrogenesis.

Cumulative rocks? An important problem to be addressed in petrogenetic studies of plutonic rocks is the evaluation of the extent to which their compositions approach those of the liquids from which they crystallized. That evaluation is especially important in the present case, since obviously cumulative rocks occur in the Capituva Massif (Janasi 1992, and above), and some authors maintain that the predominant syenites in similar occurrences bear a significant cumulative component (Conceição et al. 1991). In our opinion, however, the compositions of most of the rocks from the Capituva Massif are not far from those of the original magmas in terms of major and trace elements. Rocks from the FQS unit, in particular, are fine-grained, exhibit typical subvolcanic textures, and have low proportions of phenocrysts. As already pointed out, the compositions of the more abundant medium- to coarse grained MCS could not be derived from these magmas by feldspar accumulation. Moreover, the MCS maintain similar compositions in spite of appreciable textural variations (from porphyritic with fine- to medium-grained matrix at the borders of the massif to coarse-grained laminated towards the center). The behavior of elements such as $\mathrm{Eu}, \mathrm{Ba}$ and $\mathrm{Sr}$ also points against a significant feldspar cumulative component in these rocks, given the broadly similar contents in FQS and MCS, positive anomalies being invariably absent. It appears, therefore, that truly feldspar cumulative rocks are restricted to those very coarse-grained syenites occurring next to inclusions of country rocks (see above).

Possible extent of contamination Another typical problem to be faced with when one is dealing with strongly 


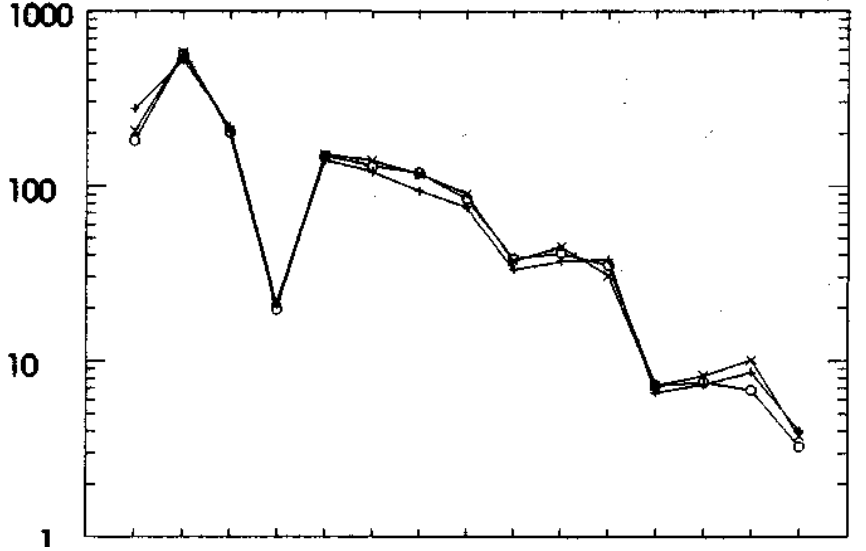

RbBaK NbLa CeSrNdPSmZr TI Dy Y Yb

Figure 8 - Incompatible-element patterns for selected Capituva Syenites, normalized to the primitive-mantle values of Sun \& McDonough (J989). Symbols as in figure 5 Figura 8 - Padrões de clementos incompatíveis para sienitos do Maciço Capituva selecionados, normalizados pelos valores de manto primitivo de Sun \& McDonough (1989). Símbolos como na figura 5

LILE-rich rocks is the evaluation of possible contributions from crustal contaminants. Isotope chemistry is often a very useful tool, but unfortunately isotopic data are as yet totally lacking for the Capituva Massif. Sr isotope data available for the neighbor and very similar Pedra Branca Massif (Winters 1981) indicate initial ratios (at $600 \mathrm{Ma}$ ) in the $0.706-0.708$ range (Janasi 1992), which seems to be somewhat large, since the rocks defining the spread come from the same outcrop and are texturally similar.

Obviously contaminated rocks are present in the Capituva Massif as heterogeneous biotite syenites that occur as small irregular bands near inclusions of gneissic granites (Janasi 1992). These rocks could riot be sampled, and thus the geochemical effects of the contamination process were not evaluated. It is obvious, anyhow, that the assimilation of the observed country rocks was not the cause of the LILE enrichment of the syenites, simply because these are far more LILE-rich than any of the known potential contaminants (chemical analyses of the gneissic granites are presented in Janasi 1992). Their LILE-rich character must therefore be related to the genesis of the primitive melts from which they derived.

Primitive intermediate magmas? The absence of exposed consanguineous basic magmas in association with syenites was taken by some authors as indicative that the latter crystallized from primitive intermediate mantle-derived magmas (e.g., Bonin \& Giret 1984, Arth \& Hanson 1975, Miller 1978). A major limitation to these hypotheses is that these rocks usually have relatively low $\mathrm{Cr}$, Ni and mg numbers (cationic $100 * \mathrm{Mg} /\left(\mathrm{Mg}+\mathrm{Fe}^{2+}\right.$; hereafter referred to as mg\#), what is indeed the case in the Capituva syenites $(\mathbf{m g \#}=44-52 ; \mathrm{Cr}<100$ ppm; $\mathrm{Ni}<70$ $\mathrm{ppm}$ ). These low values are inconsistent with magmas generated in equilibrium with the magnesian olivine typical of mantle peridotites (e.g., Thompson \& Fowler 1986), and even with the lower values (e.g., mg\# around 70) expected for ultrapotassic melts produced from phlogopiteclinopyroxenite veins (Wallace \& Carmichael 1989, Foley 1992).

The absence of more basic magmas in association with these syenites more probably reflects the higher densities of the first ones, which may preclude them to reach shallower crustal levels, except possibly during geologic events in- volving great extension; normally, only their intermediate to acid fractionates would reach these levels (e.g., Neumann 1980).

Fractionation from basic magmas? The K-trachytic (latitic) magmas from which the predominant syenites from the Capituva Massif crystallized are probably derived from basic magmas, but the nature of these and the way they fractionated is difficult to access, since no representatives of them were found.

The incompatible-element enrichment patterns of these syenites can shed some light on this problem, because some of the displayed features could have been inherited from the primitive melts (though in part emphasized by fractionation).

One important inference that can be extracted from both the REE (Fig. 5) and the incompatible-element (Fig. 8) diagrams is that extensive fractionation of feldspars is difficult to reconcile with the behavior of Eu and Sr, which show no negative anomalies when compared to elements of similar incompatibility. If so, the K-trachytic melts must have been derived from primitive magmas poor in a "basalt component" (i.e., akin to minettes) through a fractionation dominated by mafic phases, which raised the concentrations of most incompatible elements while severely depleting them in compatible elements such as $\mathrm{Ni}$ and $\mathrm{Cr}$ (by olivine + clinopyroxene extraction).

The behavior of phosporous in the small compositional range observed in the massif and the presence of apatite phenocrysts in these rocks show clearly that the magmas were P-saturated at this stage. This could indicate that the negative phosporous anomalies in the incompatible-element normalized diagrams reflect, at least in part, apatite fractionation.

The high $\mathrm{fO}_{2}$ of the magmas (Janasi 1992), which is characteristic of chemically akin basic magmas (Carmichael 1991), is most probably a reflection of their source. This should induce the early crystallization of a Fe-Ti oxide (ferri-ilmenite in the present case), maintaining the mg\# relatively high. It is however unlikely that this alone could respond for the $\mathrm{Ti}$ depletion observed in incompatibleelement normalized diagrams, where it is accompanied by a strong $\mathrm{Nb}$ trough (Fig. 8), both characteristic of the high LILE/HFSE group of potassic magmas.

PETROGENESIS AND TECTONIC SETTING High LILE/HFSE ratios (e.g., K/Ti, La/Nb, etc) are typical of arcrelated basalts and andesites, and as such are usually ascribed to a "subduction-zone component" (e.g. Gill 1981, Pearce 1983). In the last years, possible tectonic implications of this observation have been extensively applied also to syenitic rocks, and potassic syenites similar to those studied here have been considered to indicate contemporaneous subduction events (Thompson \& Fowler 1986, Guimarães 1989, Corriveau \& Gorton 1993). Some authors (e.g., Leat et al. 1986, Thompson \& Fowler 1986) proposed tectonic discrimination diagrams specifically designed for "shoshonitic and ultrapotassic rocks", that would distinguish between rocks "close" or "far" in space and/or time to subduction zones.

In parallel, the recognition that the geochemical signatures of some magmatic rocks reflect mostly the sourceareas and the physico-chemical conditions of melting, and not the tectonic environment in which they were generated has gained wide attention among geoscientists. That is particularly evident for some continental flood basalts obviously not related to subduction, especially the "low-Ti group" present in many Gondwana Mespzoic provinces (Hergt et al. 1991, Rogers 1992). The same is true, however, for many other rock types. Of particular interest for the case 
under study is the recognition that some strongly potassic magmas clearly generated during extensional periods also bear the high LILE/HFSE "arc-type fingerprint" (often well-displayed by remarkable $\mathrm{Nb}$ and $\mathrm{Ta}$ troughs in mantlenormalized incompatible-element patterns). Examples include many post-subduction (Tertiary to Cenozoic) volcanics of the western USA (Leat et al 1988, O'Brien el al. 1991) and possibly even the potassic volcanics of the Roman Magmatic Province (cf. discussions in Volmer 1990, Peccerillo 1990, Conticelli \& Peccerillo 1992). In almost all known examples, these elemental features are accompanied by peculiar isotopic characteristics which imply that these magmas should have been derived (or should at least have a major component) from mantle sources in the subcontinental lithospheric mantle (more specifically, in the mechanical boundary layer, MBL, that remains isolated from major convection and thus could preserve local inhomogeneities over geologic time; White \& McKenzie 1989). If it is admitted that the geochemical fingerprints of these rocks reflect some kind of "subduction-zone component", then this would have been introduced in the MBL during older subduction events (e.g., Dudds et al. 1987).

From the above discussion, it follows that the geologic situation, and not the geochemical signature of the K-rich Capituva Syenites, would help to decide whether they were generated under the influence of contemporaneous subduction processes or not.

Radiometric ages are still lacking for the the Capituva and Pedra Branca Massifs; Rb-Sr data for the last occurrence (Winters 1981) did not permit an isochron to be traced, because of the very low $\mathrm{Rb} / \mathrm{Sr}$ ratios of all analyzed rocks. Field evidence (Janasi 1992) indicate that these massifs constitute the last "Brasiliano" intrusives in the area. Moreover, their emplacement post-dated the major vertical displacement of the allochtonous terrane in which they are located: they lack the strong tectonic foliation present in the older granitoids, and intruded much shallower crustal levels (ca. $7 \mathrm{~kb}$ in metamorphosed country-rock mangerites and ca. $3 \mathrm{~kb}$ in syenites; Janasi 1992). On the basis of their time relations, level of emplacement and association to late faults, Janasi (1992) suggested that these massifs could be correlated with the late Brasiliano, post-collisional Itu granitoid belt (620-580 Ma, Vlach et al. 1990; see Fig. 1). Subduction-related intrusives, if to be found at all in the Guaxupé Domain, may be represented by older, "syn-orogenic" granitoids. In fact, it has been suggested that the potassic calc-alkaline suites comprising the Pinhal-Ipuiuna batholith (Vasconcellos \& Janasi 1989) and correlative occurrences (dated at ca. $640 \mathrm{Ma}$ ) exhibit some similarities with the "I-type Cordilleran granitoids".

The "arc-type" geochemical signature identified in the Capituva Massif may be inherited from a previous subduction regime, whose age is however still unclear. It is noteworthy that the emplacement of many similar potassic occurrences, although occurring under extensional regimes, immediately post-dates subduction. Many of them, however, exhibit much older Sm-Nd model ages (often taken as compatible with inferred subduction events; Dudas et al. 1987, Menzies 1989), which indeed seems to be the case in the few granitoids in the region for which $\mathrm{Sm}-\mathrm{Nd}$ data are currently available (e.g., Vlach 1993)

CONCLUSIONS The Capituva Massif was formed by the successive intrusion of four main surges of LILE- and LREE-rich, relatively oxidized syenitic magmas. The first three surges are composed of chemically similar syenites (color indices near 20-25), while more mafic (mela-syenitic) and more felsic (quartz syenitic) magmas occur in the last surge.

Rocks with an important cumulative component (alkali feldspar megacryst-rich coarse-grained syenites and maficultramafic lenses) seem to be restricted to the neighborhood of country rock inclusions.

Fine-grained quartz syenites exhibit subvolcanic textures and low proportions of phenocrysts; their composition must thus be very close to that of the magmas from which they crystallized. The predominant medium- to coarse-grained syenites seem to constitute a relatively homogeneous chemical group that is slightly but consistently different from the fine-grained quartz syenites. A significant feldspar cumulative component can be ruled out also in these coarser rocks, on the basis of their chemical homogeneity in spite of large textural variations, the absence of positive $\mathrm{Eu}, \mathrm{Ba}$ and $\mathrm{Sr}$ anomalies (with abundances comparable to those found in the fine-grained varieties), and a composition in terms of normative feldspar components that is incompatible with alkali-feldspar accumulation from magmas equivalent to the fine-grained quartz syenites.

The absence of basic magmas genetically associated with the K-syenites is a common feature in similar massifs, but it is difficult to admit that these intermediate magmas are primitive, given their low $\mathrm{Ni}$ and $\mathrm{Cr}$ and high $\mathrm{SiO}_{2}$ contents. More probably, the parental basic magmas did not ascend to shallow crustal levels, reached only by the less dense magmas that remained after early fractionation of mafic minerals (clinopyroxene; \pm olivine, phlogopite). Extensive plagioclase fractionation at these early stages is unlikely, since no negative $\mathrm{Sr}$ or $\mathrm{Eu}$ anomalies are observed in mantlenormalized incompatible-element patterns. The most primitive magmas in this series must therefore have been similar to minettes.

The K-syenites show a typical high LILE/HFSE signature that nevertheless does not imply an origin contemporaneous to subduction, since geologic evidence indicates that they were generated in a post-collisional environment. Most probably, this signature reflects the chemistry of a sourcearea (in the subcontinental lithosphere) that still preserves the signature of older "enrichment" events (related to a previous subduction of yet unknown age and/or to episodic veining from small-fraction LILE-rich asthenospheric magmas).

Acknowledgements This study is pan of a Doctoral Thesis presented at the University of São Paulo. Financial support was supplied by grants form FAPESP (Proc. 907 0940) and FINEP (42.86.091.00). I acknowledge reviews by $\mathrm{H}$. Ulbrich and one anonymous referee that contributed to improve this article.

\section{REFERENCES}

ARTH, J.G. \& HANSON, G.N. 1975. Geochemistry and origin of the early Precambrian crust of northeastern Minesotta. Geochim. Cosmochim. Acta, 39:325-362.

BONIN, B. \& GIRET, A. 1984. The plutonic alkaline series: the problem of their origin and differentiation, the role of their mineralogical assemblages. Phys. Earth Planet. Int., 35:212-221.

BOYNTON, W.'V. 1984. Cosmochemistry of the rare-earth elements: meteorite studies. In: H ANDERSON, P. ed. Rare-earth Elements Geochemistry. Amsterdam, Elsevier. p. 63-114.
CAMPOS NETO, M.C.; B ASEI, M. A.S.; ALVES, F.R.; VASCONCELLOS, A.C.B.C. 1984. A nappe de cavalgamento de Socorro (SP-MG). In: CONOR. BRAS. GEOL. 34. Rio de Janeiro, 1984. Anais... Rio de Janeiro, SBG. v. 6, p. 2854-2868.

CAMPOS NETO, M.C. FIGUEIREDO, M.C.H· JANASI, V.A.; BASEI, M.A.S.; FRYER, B.J. 1988. The São José do Rio Pardo mangeriticgranitic suite, southeastern Brazil. Ceochim. Brasil., 2:185-199.

CARMICHAEL, I.S.E. 1991. The redox states of basic magmas: a reflection of their source areas? Contrib. Mineral. Petrol., 106:129-141. 
CONCEIĈ̃̃O, H.; SABATE, P.; BONIN, B. 1991. The Itiuba alkaline syenite massif, Bahia (Brazil): mineralogical, geochemical and petrological constraints - relation to the genesis of the rapakivi magmatism. Free. Res., 51:283-314.

CONTICELLI, S. \& PECCERILLO, A. 1992. Petrology and geochemistry of potassic and ultrapotassic volcanism in central Italy: petrogenesis and inferences on the evolution of the mantle sources. Lithos, 28:221-240.

CORRIVEAU, L. \& GORTON, M.P. 1993. Coexisting K-rich alkaline and shoshonitic magmatism of arc affinities in the Proterozoic: a reassessment of syenitic stocks in the southwestern Grenville Province. Contrib. Mineral. Petrol., 113:262-279.

DUDAS, F.6.; CARLSON, R.W.; EGGLER, D.H. 1987. Regional Middle Proterozoic enrichment of the subcontinental mantle source of igneous rocks from central Montana. Geology, 15:22-25.

FIGUE1REDO, M.C.H. 1981. Geoqufmica das rochas metamorficas de alto grau do nordeste da Bahia, Brasil. In: Geologia e Recursos Minerals do Estado da Bahia. p. 1-71. Salvador, SME. (Textos Basicos 4).

FOLEY, S. 1992. Petrological characterization of the source components of potassic magmas: geochemical and experimental constraints. Lithos, 28:187-204.

FOLEY, S.F.; VENTURELLY, G.; GREEN, D.H.; TOSCANI, L. 1987. The ultrapotassic rocks: characteristics, classification, and constraints for petrogenetic models.Earth-Sci. Rev., 24:81-134.

GILL, J.B. 1981. Orogenic andesites and plate tectonics. In: GILL, J.B. ed. Andesites. Berlin, Springer, p. 230-256.

GUIMARÃES, I.P. 1989. The Petrological Evolutions and Tectonic Associations of the Bom Jardim Complex, Pernambnco State, NE Brazil. London. 424 p. (PhD Thesis, The Imperial College).

GUIMARÃES, I.P. \& SILVA, A.F. F F 1990 . Magmatismo intrusivo shoshonítico na Faixa Pajeu-Paraíba: o Complexo Bom Jardim. In: CONGR. BRAS. GEOL., 36. Natal, 1990. Anais... Natal, SBG. v. 4, p. 1739-1751.

HADDAD, R.C. \& JANASI, V.A. 1992. Petrografia do batólito granitóide Pinhal-Ipuiúna (SP-MG). In: CONGR. BRAS. GEOL., 37. São Paulo, 1992. Boletim de Resumos Expandidos... São Paulo, SBG. v. 1, p. 394-396.

HASUI, Y. \& OLIVEIRA, M.A.F. 1984. Provmcia Mantiqueira - Setor Central. In: ALMEIDA, F.F.M. \& HASUI, Y. eds. O Pre-Cambriano do Brasil. São Paulo, Ed. Blucher. 378 p.

HERGT, J.M.; PEATE, D.W.; HAWKESWORTH, C.J. 1991. The petrogenesis of Mesozoic Gondwana low-Ti fiood basalts. Earth Planet. Sci. Lett., 105:134-148.

JANASI, V.A. 1992. Rochas Sieníticas e Mangerítico-Charnoquíticas Neoproterozoicas da Regido entre Caldas e Campestre, MG: Aspectos Petrológicos. São Paulo. 298 p. (Tese de Doutoramento, IG/USP).

JANASI, V.A. \& ULBRICH, H.H.G.J. 1991. Late Proterozoic granitoid magmatism in the State of São Paulo, southeastern Brazil. Prec. Res., 51:524-534.

JOST, H.; BROD, J.A.; HOLZ, M.; KUHN, A.; FLOR, M.A.D.; KRONBAUER, A.; DIELEMBURG, S. 1985. Geologia estrutural, petrografia e petrologia do Sienilo Piquiri (Proterozóico Superior), Rio Grande do Sul. In: SIMP. SUL-BRAS. GEOL., 2.Atas... Porto Alegre, SBG. p. 63-81.

Le BAS, M.J.; Le MAITRE, R.W.; STRECKEISEN, A.; \& ZANETTIN, B. 1986. A chemical classification of volcanic rocks based on the Total Alkalis-Silica Diagram. J. Petrol., 27:745-750.

LEAT, P.T; THOMPSON, R.N.; MORRISON, M.A.; HENDRY, G.L.; TRAYHORN, S. 1986. Geodynamic significance of post-Variscan intrusive and extrusive potassic magmatism in SW England. Trans. $R$. Soc. Edinburg, 77:349-360.

LEAT, P.T.; THOMPSON, R.N.; MORRISON, M.A.; HENDRY, G.L.; DICKIN, A.P. 1988. Silicic magmas derived by fractional crystallization from Miocene minette, Elkhead Mountains, Colorado. Mineral. Mag., 52:577-585.

MENZIES, M. 1989. Cratonic, circumcratonic and oceanic mantle domains beneath the western United Slates. J. Geophys. Res., 94:7899-7915.

MILLER, C.J. 1978. Monzonitic plutons, California, and a model for the generation of alkali-rich, near silica-saturated magmas. Contrib. Mineral. Petrol. 67:349-355.

NEKVASIL, H. 1990. Reaction relations in the granite system: Implications for trachytic and syenitic magmas.Aw. Mineral., 75:560-571.

NEUMANN, E.R. 1980. Petrogenesis of the Oslo region larvikites and associated rocks.7. Petrol., 21:499-531.

O'BRIEN, H.E.; IRVING, A.J.; McCALLUM, I.S. 1991. Eocene potassic magmatism in the Highwood Mountains, Montana: petrology, geochemisty, and tectonic implications.J. Geophys. Res., 96:3237-13260

PEARCE, J.A. 1983. Role of the sub-continental lithosphere in magma genesis at active continental margins. In: HAWKESWORTH, C.J. \& NORRY, M.J. eds. Continental Basalts and Mantle Xenoliths. Cheshire, UK, Shiva Publ. Ltd. p. 230-249.

PEARCE, J.A.; HARRIS, N.B.W.; TINDLE, A.G. 1984. Trace-element discrimination diagrams for the tectonic interpretation of granitic rocks. J. Petrol., 25:956-983.

PECCERILLO, A. 1990. On the origin of the Italian potassic magmas Comments. Chem. Geol., 85:183-191.

PECCERILLO, A. \& TAYLOR, S.R. 1976. Geochemistry of Eocene calcalkaline rocks from the Kastamoru area, northern Turkey. Contrib. Mineral. Petrol., 58:63-81.

ROGERS, N.W. 1992. Potassic magmatism as a key to trace-element enrichment processes in the upper mantle.J. Volcanol. Geotherm. Res. 50:85-99.

STORMER, J.C., Jr. \& NICHOLLS, J. 1978. XLFRAC: a program for the interactive testing of magmatic differentiation models. Comput. \& Geosc., 4:143-159.

THOMPSON, R.N. \& FOWLER, M.B. 1986. Subduction-related shoshonitic and ultrapotassic magmatism: a study of Siluro-Ordovician syenites from the Scottish Caledonides. Contrib. Mineral. Petrol., 94:507-522.

VASCONCELLOS, A.C.B.C. 1988. O Grupo Andrelandia na Regiao de Ouro Fino, MG. São Paulo. (Dissertafao de Mestrado, IG/USP).

VASCONCELLOS, A.C.B.C. \& JANASI, V.A. 1989. Mapeamento faciológico do batólito granitóide cálcio-alcalino de Pinhal-Ipuiúna (MG). In: SIMP. GEOL. MINAS GERAIS, 6. Belo Horizonte, 1989. Atas... Belo Horizonte, SBG/NMG. p. 65-69.

VASCONCELLOS, A.C.B.C.; HARRIS, N.B.W.; TINDLE, A.G. 1991. The relationship between metamorphism and tectonics: evidence from the Socorro-Guaxupé Thrust Nappe, southestern Brazil. In: TUISKU, P. \& LAAJAKI, K. eds. Metamorphism, Deformation and Structure of the Crust. Res Terrae. Finland, University of Oulu. v. A-5, p. 86.

VLACH, S.R.F. 1993. Geologia e petrologia dos granitoides da regiao de Morungaba. São Paulo. 414 p. (Tese de Doutoramento, IG/USP). $414 \mathrm{p}$.

VLACH, S.R.F.; JANASI, V.A.; VASCONCELLOS, A.C.B.C. 1990. The Itu Belt: associated calc-alkaline and aluminous A-type late Brasiliano granitoids in the States of São Paulo and Parana, Southern Brazil. In: CONGR. BRAS. GEOL., 36. Natal, 1990. Anais... Natal, SBG. v.4, p. 1700-1711.

VOLMER, R. 1990. On the origin of the Italian potassic magmas - Reply. Chem. Geol., 85:191-196.

WALLACE, P. \& CARMICHAEL, I.S.E. 1989. Minette lavas and associated leucitites from the Western Front of the Mexican Volcanic Belt: petrology, chemistry, and origin. Contrib. Mineral. Petrol., 103:470-492.

WERNICK, E. \& PENALVA, F. 1980. Contribuição a geologia do Grupo Pinhal (SP e MG). Rev. Bras. Geoc., 10:43-62.

WHITE, R.S. \& McKENZIE, D. 1989. Magmatism at rift zones: the generation of volcanic continental margins and flood basalts. J. Geophys. Res., 94:7685-7729.

WINTERS, A. A.M. 1981 A Geologia do Maciço Sienítico da Pedra Branca, Caldas-MG. São Paulo. 92 p. (Dissertac.aode Mestrado, IG/USP).

MANUSCRITO A774

Recebido em 30 de niarco de 1993

Revisao do autor em 3 de maio de 1993 Revisao aceita em 14 de maio de 1993 